\title{
Young restored forests increase seedling recruitment in abandoned pastures in the Southern Atlantic rainforest
}

\author{
Flora H.M. Leitão ${ }^{1}$, Marcia C.M. Marques ${ }^{1} \&$ Eliane Ceccon ${ }^{2}$ \\ 1. Laboratório de Ecologia Vegetal, Departamento de Botânica, SCB, Universidade Federal do Paraná; Caixa Postal \\ 19.031, 81531-980 Curitiba, PR, Brazil; mmarques@ufpr.br \\ 2. Centro Regional de Investigaciones Multidisciplinarias, Universidad Nacional Autónoma de México; Av. Universidad \\ s/n, Circuito 2 Colonia Chamilpa, Cuernavaca, Morelos, 62210, Mexico; ececcon@miranda.ecologia.unam.mx
}

\author{
Received 21-IX-2009. Corrected 01-V-2010. Accepted 03-VI-2010.
}

\begin{abstract}
Planting seedlings is a common technique for abandoned pastures restoration in the tropics, supposedly by increasing the seedling recruitment and accelerating succession. In this study we evaluated the role of a young restored forest (one year old) in enhancing seedling establishment from two sources (seed rain and seed bank), in the Atlantic Rainforest region in Southern Brazil. We compared abandoned pasture, young restored forest and old-growth forest with respect to the seedlings recruited from different sources, by monitoring 40 permanent plots $(0.5 \mathrm{mx} 0.5 \mathrm{~m})$ over 20 months. From the three studied areas a total of 392 seedlings of 53 species were recruited. Species were mainly herbaceous $(85 \%)$, pioneers $(88 \%)$, zoochorous $(51 \%)$ and small-seeded species $(60 \%)$. Seedling recruitment from the seed bank (density and species richness) was higher and dominated by herbaceous species in the abandoned pasture and in the young restored forest; on the other hand, the recruitment of woody species from seed rain was more pronounced in the old-growth forest. The young restored forest increased the species richness of woody seedlings recruitment from the seed bank (two-fold) and from seed rain (three-fold) compared to the abandoned pasture. Also, the seedling density in young restored forest was still higher than abandoned pastures (seed bank: four times; seed rain: ten times). Our results show that even young restored areas enhance the establishment of woody species and should be considered an important step for pasture restoration. Rev. Biol. Trop. 58 (4): 1271-1282. Epub 2010 December 01.
\end{abstract}

Key words: seed rain, seed bank, restoration, recruitment, tropical forest.

One of the most important causes of deforestation of tropical forests in recent decades has been the creation of pastures for cattle grazing (Fearnside 1993). Pastures drastically change the habitat for native woody species by promoting soil nutrient exhaustion and soil compaction, altering water-retention capacity (Rasiah et al. 2004) and by introducing exotic grasses that interfere with seedling establishment (Aide et al. 1995). An increasing interest in restoring abandoned pastures in tropical regions has been observed recently (Florentine \& Westbrooke 2004a), because tropical rainforests in these regions maintain biodiversity and ecological services (Erskine et al. 2005).
Success in the restoration of abandoned pastures depends on factors such as disturbance severity, area and distance from seed source (Pakeman \& Small 2005). In less disturbed or larger areas, the natural or assisted regeneration may be an inexpensive and viable alternative to drive vegetation toward a pristine state (Aide et al. 2000, Hooper et al. 2005, Vieira \& Scariot 2006, Shono et al. 2007). Nevertheless, in more disturbed or small areas, the introduction of restored forest by planting native trees may be the better choice for restoring diversity in tropical areas (Aide et al. 2000, Florentine \& Westbrooke 2004b, Lamb et al. 2005). Planting forests contributes by both rapidly covering the 
degraded area with a set of local species and accelerating ecological succession.

Newly planted trees are important to attract potential seed dispersers and increase the seed shadow of abandoned pastures (Yarranton \& Morrison 1974, Holl 1998, Carriére et al. 2002). In less damaged soils, seeds remaining in the soil should provide an additional input of new individuals (Zimmerman et al. 2000). Thus, propagules act as an acceleratory mechanism for seedling recruitment and ecological succession in abandoned pastures (Zimmerman et al. 2000, Aide et al. 2000). In fact, seed production and seedling recruitment set the stage for all further dynamic processes (Shupp et al. 2002) and are crucial for community dynamics (Brokaw 1982, Lieberman \& Lieberman 1987, Swaine et al. 1987). However, little is known about the effective role of seed sources in restoration areas with the introduction of native trees (Guariguata-Urbano et al. 1995, BenítezMalvido et al. 2001). In this way, knowledge of the potential and effectiveness of seed banks and seed rain in the recruitment of new individuals in restored forests is an important step for planning a restoration (Sarmiento et al. 2003, Ruiz-Jaen \& Aide 2005). Specifically, in the first years after planting, the seedling source may determine the successional trajectory and the success of the restoration.

The Atlantic Rainforest is a unique and extremely diverse mix of vegetation types, originally distributed along virtually the entire coast of Brazil (Morellato \& Haddad 2000, Scarano 2002). However, due to disturbances caused by demographic expansion and agriculture, today only about $7.5 \%$ of this biome remains, mostly as preserved fragments (Myers et al. 2000, Morellato \& Haddad 2000, Capobianco 2001). On the Southern coast of Brazil, the Atlantic Forest comprises a mosaic of pastures and agriculture lands mixed with successional and well preserved forests (Roderjan \& Kuniyoshi 1988). In this region, a large project to restore abandoned pastures to improve forest diversity and function started in 2000 (Ferretti $\&$ Britez 2006). In this study we evaluated the efficiency of young restored forests to improve the seedling recruitment and accelerate the succession in abandoned pastures in Southern Brazil. We analyzed the seedling emergence from seed rain and the seed bank in a young restored forest compared to an abandoned pasture and an old-growth forest. Specifically we addressed the questions: (1) whether the young restored area is comparable with newly abandoned pasture and old-growth forest in terms of seed floristic density and species richness; (2) whether the relative importance of seedling recruitment from seed rain and seed bank are different among sites.

\section{MATERIALS AND METHODS}

Study site: The study took place in the 8 600ha Rio Cachoeira Natural Reserve $\left(25^{\circ} 19^{\prime} 15^{\prime \prime} \mathrm{S}, 45^{\circ} 42^{\prime} 24^{\prime \prime} \mathrm{W}\right)$ on the coast of the state of Paraná, in the South of Brazil. The site belongs to the non-governmental organization Sociedade de Pesquisa em Vida Selvagem e Educação Ambiental (SPVS: Society for Wildlife Research and Environmental Education). The climate type is Cfa in the Köppen classification system (i.e., humid subtropical and mesothermic with neither a pronounced dry season, nor hard frosts; Ferreti \& Britez 2006). The 25-year annual precipitation and temperature average were $2218 \mathrm{~mm}$ and $21^{\circ} \mathrm{C}$, respectively. Altitudes range from sea level to 900m (Ferretti \& Britez 2006).

The predominant vegetation type is Atlantic Tropical Rainforest, which comprises a variety of vegetation typologies from lowland and alluvial to montane forests (Veloso et al. 1991). Despite this region being one of the best-preserved Atlantic Rainforest fragments in Brazil, a part of the plain and other welldrained areas were converted to pasture for buffalo ranching. Since 2000, these disturbed areas have been either abandoned for natural regeneration or restored with native species. Currently, the reserve is a mosaic of planted, successional and undisturbed forests in an altitudinal range (Ferretti \& Britez 2006). For this study we chose three areas in this mosaic: recently abandoned pasture, young (12-month 
old) restored forest and old growth forest. All areas were distanced $\sim 2 \mathrm{~km}$ apart and could be characterized as the following:

Abandoned pasture: this area was originally covered by lowland Atlantic Rainforest, prior to being converted to pasture by logging and removal of all roots and sticks in the late 1980s. The African grass Brachiaria humidicola was used for pasture and buffalo grazing for 15-20 years. The pasture was abandoned for four months before the experiment and some shrubs (Melastomataceae and Asteraceae species) and small tree (Myrtaceae) seedlings were growing naturally in the area. The experimental area is $\sim 800 \mathrm{~m}$ from the closest forest remnant.

Young restored forest: this area was originally covered by lowland Atlantic Rainforest and was used for buffalo grazing in the same condition as the abandoned pasture area. Following the removal of the buffalo, native tree seedlings were planted (December 2003) by the SPVS restoration project (Ferreti \& Britez 2006). The area was restored using only pioneer species (Mimosa bimucronata, Schizolobium parahybum, Psidium cattleianum, Trema micrantha, Inga edulis, Inga marginata, Cordia sellowiana, Cytharexylum myrianthum) and seedlings were distributed in a $2.5 \mathrm{~m} \times 1.6 \mathrm{~m}$ grid pattern. At the beginning of the seed rain and seed bank experiment in January 2005, the restored forest was 12 months old, average trees height was $\sim 4 \mathrm{~m}$ and approximately all planted individuals were adult. The experimental area was $\sim 800 \mathrm{~m}$ from the nearest forest remnant.

Old growth forest: this area was a welldeveloped sub-montane forest that was used for pasture and abandoned about 120 years ago. The forest has three well-defined strata (canopy: 20m in height, intermediate stratum and understory) with the understory being shaded and sparse.

Experimental design: At each site we established ten parallel transects, spaced $10 \mathrm{~m}$ apart. Two permanent plots $(0.5 \mathrm{~m} \times 0.5 \mathrm{~m})$ were systematically placed $10 \mathrm{~m}$ apart in each transect. The treatments were assigned randomly among two plots per transect, giving a total of 20 plots in each treatment. Therefore, each treatment had 10 replicates (one in each transect) and occupied a total area of $2.5 \mathrm{~m}^{2}$.

The experiment was designed to assess the seedling recruitment in the three areas and the relative contribution of seed rain and seed bank to seedling recruitment within habitats. To evaluate the contribution of seed rain we removed all vegetation, fine litter, and the top $1 \mathrm{~cm}$ of soil from ten randomly selected plots. Three liters of boiling water were applied twice per day, in the first five days of the experiment. The second addition of boiling water was necessary to kill any seeds that could survive high temperatures and/or germinated, according to the methodology used successfully by BenítezMalvido et al. (2001). Although fire (or hot water) can be important to break the dormancy of seeds in the first layers of soil in dry forests and savannah, this might not occur in humid tropical tree species (Vázquez-Yanes 1974). Thus, we assumed that this method was sufficient to eliminate all seeds from the soil. To evaluate the contribution of the seed bank we also removed all vegetation, fine litter and $1 \mathrm{~cm}$ of soil in ten randomly selected plots. Each plot was then completely covered with $1 \mathrm{~mm}$ transparent mesh mounted on a $40 \mathrm{~cm}$ tall wire frame to eliminate seed fall inside the plots (Benítez-Malvido et al. 2001).

Seedling emergence was recorded and seedlings were labeled and identified in the plots every four months for a total of 20 months. Seedlings were identified in the field and at the end of the experiment, seedlings that emerged and survived in all treatments, were collected and their identification confirmed. We compared samples with a seedling reference collection for Atlantic Rainforest in the Laboratory of Plant Ecology, Federal University of Paraná. Whenever possible, seedlings were determined to the family level.

Seedling species were first classified in two classes: woody species, considering trees and shrubs, and herbaceous species, considering 
vines, epiphytes and terrestrial herbs. We adopted this procedure because at the morphospecies level, the stem texture is easily recognizable (woody or not) but it is more difficult to identify the species with certainty. Species were also classified in successional categories (pioneer and non-pioneer, according to Swaine \& Whitmore 1988), dispersal syndrome (zoochorous, anemochorous and autochorous, according to Pijl 1972) and seed size. In this case, seeds from a reference collection (Laboratory of Plant Ecology) were measured in length and categorized as small $(0.01-5.00 \mathrm{~mm})$, medium $(5.01-10.00 \mathrm{~mm})$ and large $(10.01-25.00 \mathrm{~mm})$. When species classification was not possible in the laboratory, we consulted specific literature (regional and South American flora) to get the morphological information necessary for species classification.

A parallel experiment was designed to evaluate the potential effect of vegetation removal in the seedling recruitment from seed rain and seed bank evaluation above. In each area (abandoned pasture, young restored forest and old growth forest) a set of 10 plots was randomly placed in transects. In each plot we removed the vegetation, fine litter and $1 \mathrm{~cm}$ of topsoil. Additionally, we placed in the three areas a set of 10 plots where vegetation, litter and soil were maintained as control plots. The mean seedling density in the cover-removed plots did not differ from the non-removed plots, for herbaceous and woody species and all sites ( $t$ test, $p>0.05$ ). Thus, we considered that cover removal did not interfere with seedling recruitment and did not bias the main experiment. In contrast to other related experiments, which have demonstrated that litter removal may limit or promote seedling emergence (Molofsky \& Augspurger 1992, Holl 1999) by removing vegetation and soil, we altered drastically the seeds' habitat by also removing seeds and underground structures (steams or roots) from the plots and thus any possibility of seed germination or sprouting. Furthermore, cover removal resulted in a virtually barren habitat where seedling emergence occurred in the same density as non-removed and undisturbed plots at the end of the experiment.

Analyses: At the end of the $20^{\text {th }}$ month, seedlings that had emerged in both treatments were examined and compared among treatments and areas. We analyzed the data set to test differences among treatments and sites.

Since species life forms strongly influence successional dynamics in tropical forests (Guariguata \& Ostertag 2001), the remaining analyses were conducted considering woody species and herbaceous species separately. Different sites and treatments were compared for floristic similarity using the Sorensen's similarity index (Müller-Dombois \& Ellenberg 1974). Species life-forms abundances were compared among areas using the independence test (Zar 1999), considering individual numbers in each category and site. A chi-square test (Zar 1999) was used to analyze the distribution of recruited plants' density and species richness from the seed bank and seed rain among habitats.

\section{RESULTS}

A total of 392 individuals of 53 angiosperm species were recorded during 20 months from the three study sites (Appendix 1). From abandoned pasture, 158 individuals of 21 species were recorded; for the young restored forest and the old-growth forest, 219 individuals (16 species) and 15 (nine species) were recorded, respectively. For the seed bank plots, 243 seedlings (23 species) and in the seed rain plots, 149 seedlings (29 species) were recorded. Considering all treatments, the families with the highest diversity were Melastomataceae (five species), Myrtaceae and Rubiaceae (four species each, Appendix 1). Some species were important in terms of density: Sida rhombifolia (herbaceous, autochorous, pioneer and small-seeded species; 50.4 seedlings $/ \mathrm{m}^{2}$ ), Clidemia hirta (woody, pioneer, zoochorous and small-seeded species; 26.8 seedlings $/ \mathrm{m}^{2}$ ) and Diodia radula (herbaceous, authocorous, pioneer, small-seeded species; 21.6 seedlings $/ \mathrm{m}^{2}$; Appendix 1). In general, there was no floristic 
similarity ( $\mathrm{S}=$ Sorensen's similarity index) of recruited seedlings among sites $(\mathrm{S}=0)$. Floristic similarities were only found between abandoned pasture and young restored forest, for woody species in the seed rain $(S=0.50)$, the seed bank $(S=0.67)$ and between abandoned pasture and young restored forest for herbaceous species in the seed bank $(\mathrm{S}=0.17)$.

Considering all treatments (53 species), the species were mainly herbaceous $(62 \%)$, pioneers $(58 \%)$, zoochorous $(43 \%)$ and smallseeded $(66 \%)$. The distributions of recruited seedlings in the three sites depended on their life form, successional category, dispersal mode and seed size (Table 1). There was a predominance of herbaceous, pioneer, zoochorous and small-seeded species in the abandoned pasture. In the young restored forest, species were mainly herbaceous, pioneer, autochorous and small-seeded. Finally, in the old-growth forest most of species were woody, non-pioneer, zoochorous and medium to large-seeded (Table 1).

The total density of recruited seedlings was greater for herbaceous than woody species (32.2 and 7.0 seedlings $/ \mathrm{m}^{2}$ ) and for the seed bank than for seed rain (24.3 and 14.9 seedlings $/ \mathrm{m}^{2}$ ). The density of recruited seedlings from the seed bank and seed rain was depended on the site (Figs. 1a and 1b) for both herbaceous $(\mathrm{G}=16.4, \mathrm{df}=2, \mathrm{p}<0.05)$ and woody species $(\mathrm{G}=11.2, \mathrm{df}=2, \mathrm{p}<0.05)$. In the young restored forest, the herbaceous seedling density in seed rain was more than twice the density of the abandoned pasture and six times the density of the old-growth forest; a high seedling density was also found in the seed bank of the young restored forest (Fig. 1a). Considering only woody species, the seedling densities in the seed bank and seed rain in the young restored forest were much higher than in abandoned pasture and old-growth forest (Fig. 1b).

The total species richness in the three sites was also higher for herbaceous than woody species (3.0 and 0.9 species $/ \mathrm{m}^{2}$, respectively), but higher for seed rain than seed bank (2.9 and $2.3 \mathrm{species} / \mathrm{m}^{2}$, respectively). The species richness in seed rain and seed bank was different among sites for herbaceous species $\left(\chi^{2}=31.06\right.$, $\mathrm{df}=2, \mathrm{p}<0.05)$, but no statistical difference was detected for woody species $\left(\chi^{2}=5.35, \mathrm{df}=2\right.$, $\mathrm{p}>0.05)$. The species richness of herbaceous species in the young restored forest was four times higher than the old growth-forest for both the seed bank and seed rain. When compared to the abandoned pasture, the seed rain had

TABLE 1

Species richness (and percentage of total) of recruited seedlings according to ecological attributes, in three areas of the Rio Cachoeira Reserve, Brazil

\begin{tabular}{|c|c|c|c|c|c|}
\hline & & $\begin{array}{c}\text { Abandoned } \\
\text { Pasture }\end{array}$ & $\begin{array}{l}\text { Young restored } \\
\text { forest }\end{array}$ & $\begin{array}{l}\text { Old-growth } \\
\text { forest }\end{array}$ & $G$ test \\
\hline Life-Form & $\begin{array}{l}\text { Herbaceous } \\
\text { Woody }\end{array}$ & $\begin{array}{c}21(75 \%) \\
7(25 \%)\end{array}$ & $\begin{array}{c}16(76 \%) \\
5(24 \%)\end{array}$ & $\begin{array}{c}5(33 \%) \\
10(66 \%)\end{array}$ & $\begin{array}{c}\mathrm{G}=8.10 ; \\
\mathrm{DF}=2 ; \mathrm{p}<0.02\end{array}$ \\
\hline Successional category & $\begin{array}{l}\text { Pioneer } \\
\text { Non-pioneer }\end{array}$ & $\begin{array}{c}21(95 \%) \\
1(5 \%)\end{array}$ & $\begin{array}{c}19(95 \%) \\
1(5 \%)\end{array}$ & $\begin{array}{l}2(23 \%) \\
7(77 \%)\end{array}$ & $\begin{array}{c}\mathrm{G}=21.92 ; \\
\mathrm{DF}=2 ; \mathrm{p}<0.0001\end{array}$ \\
\hline Dispersal mode & $\begin{array}{l}\text { Zoochorous } \\
\text { Anemochorous } \\
\text { Autochorous }\end{array}$ & $\begin{array}{l}12(60 \%) \\
2(10 \%) \\
8(30 \%)\end{array}$ & $\begin{array}{l}8(42 \%) \\
2(11 \%) \\
9(47 \%)\end{array}$ & $\begin{array}{c}9(90 \%) \\
1(10 \%) \\
0\end{array}$ & $\begin{array}{c}\mathrm{G}=7.05 ; \\
\mathrm{DF}=2 ; \mathrm{p}<0.03\end{array}$ \\
\hline Seed size & $\begin{array}{l}\text { Small }(0.01-5.00 \mathrm{~mm}) \\
\text { Medium }(5.01-10.00 \mathrm{~mm}) \\
\text { Large }(10.01-25.00 \mathrm{~mm})\end{array}$ & $\begin{array}{c}25(100 \%) \\
0 \\
0\end{array}$ & $\begin{array}{c}19(91 \%) \\
2(9 \%) \\
0\end{array}$ & $\begin{array}{l}2(26 \%) \\
3(37 \%) \\
3(37 \%)\end{array}$ & $\begin{array}{c}\mathrm{G}=23.09 ; \\
\mathrm{DF}=2 ; \mathrm{p}<0.0001\end{array}$ \\
\hline Total species richness* & & 28 & 21 & 15 & \\
\hline
\end{tabular}


A. Herbaceous species density

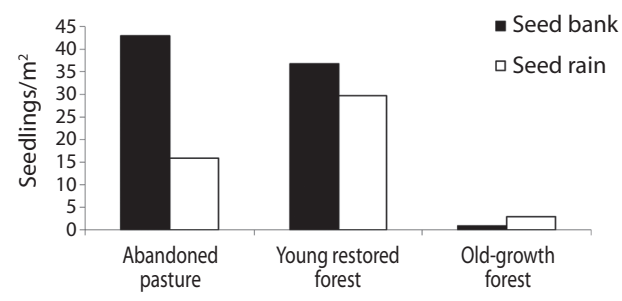

C. Herbaceous species richness

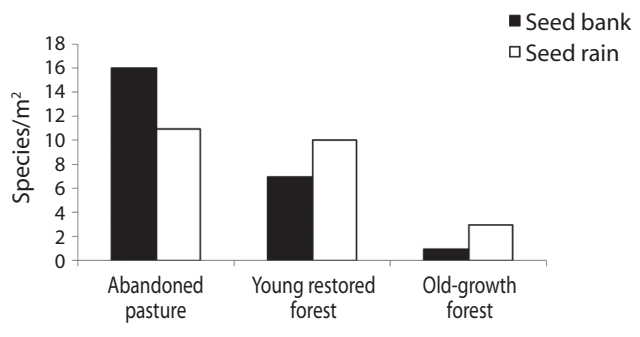

B. Woody species density

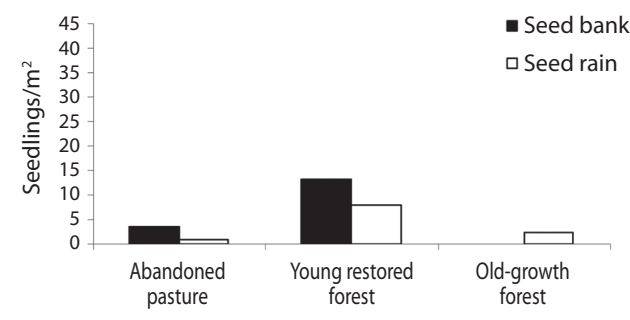

D. Woody species richness

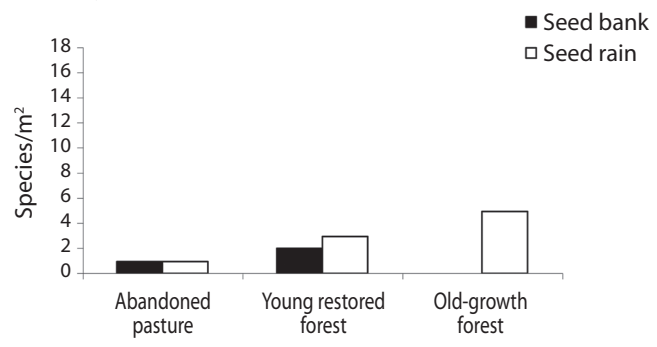

Fig. 1. Total seedling recruitment from seed rain and the seed bank in three different sites in Rio Cachoeira Reserve, Brazil. (A) seedling density of herbaceous species; (B) seedling density of woody species; (C) species richness of herbaceous species; (D) species richness of woody species. All p<0.05.

similar species richness, while the seed bank in the young restored forest had lower species richness (Fig. 1c). Considering woody species, the young restored forest species richness was twice that abandoned pasture for both the seed bank and seed rain (Fig. 1d). The species richness of woody seedlings recruited from seed rain of old-growth forest was higher than other two sites, but no seedlings were recruited from the seed bank (Fig. 1d).

\section{DISCUSSION}

Species characteristics in seed rain and seed bank: Plant recruitment from seeds plays an important role in tropical forest regeneration, by enhancing the genetic variability and contributing to forest diversity and structure (Harper 1977, Ceccon et al. 2003, Ceccon et al. 2004, Simões \& Marques 2007). In Rio Cachoeira Reserve seedling emergence from seed banks and seed rain is an important source of diversity (53 plant species) in the three contrasting sites studied. These findings indicate the great potential for restoration of the Atlantic Rainforest in Brazil.

The three study areas differed in species composition (Sorensen's similarity index $<0.67$ ). Whereas abandoned pasture and young restored forest were floristically similar, the old-growth forest presented a very different habitat for seed germination. These differences were not surprising considering the large age gap between study areas (abandoned pasture and young restored forest: less than two years; old-growth forest: 120 years), consequently resulting in different conditions for seed germination. In addition, even though the successional process is known, stochastic factors have strong effects on establishing a community's composition (Mabberley 1992) and in a way that it makes each community unique for each area.

Melastomataceae was the most important family in the woody species regeneration. 
This is an abundant group in the Neotropics, occurring generally as understory shrubs (Ellison et al. 1993) and is especially prevalent in regrowth forest stands. The zoochoric and pioneer species Clidemia hirta was important mainly in the young restored forest. This shrub colonizes naturally and anthropogenically disturbed open areas (De Walt et al. 2004) and its large crops (pers. obs.) possibly are food source for birds. The observation that it promotes high rates of recruitment in the study sites suggests that it is a potential species for future restoration programs.

The distribution of species characteristics varied among sites. The abandoned pasture and young restored forest were dominated by herbaceous, pioneer, zoochorous or autochorous and small seeded species. These attributes are usually associated with high seed production and dispersal (Bazzaz \& Ackerly 1992), short-lived plants, less competitive seedlings (Harper et al. 1970) and light demanding species (Grime et al. 1981). Although their distribution is restricted to bare soil and disturbed areas (Bazzaz \& Picket 1980, Bazzaz \& Ackerly 1992), the presence of this species in abandoned pastures is a first step to overcome the grass layer and start the successional process. Thus, the abandoned pasture and young restored forest seedlings were dominated by facilitating species.

On the other hand, the old-growth forest was dominated by woody, non-pioneer, zoochorous and medium to large-seeded species. These seedling species are more competitive (Allsopp \& Stock 1995) in the high diversity community of the old-growth forest. Nevertheless, these seeds are short-lived, more susceptible to predation (Van der Wall 1994) and may become non viable in the seed bank after long periods (Metcalfe \& Turner 1998). It is possible that species with these characteristics are slowly recruited in the successional process from the abandoned pasture to the old-growth forest.

Seed source and forest restoration: The availability and characteristics of the seed source may drive the success of a restoration process in disturbed tropical areas (Miller \& Kauffman 1998). Our results from Rio Cachoeira Reserve show that the importance of a seed bank or seed rain in forest regeneration depends on the successional level and plant species present in the site and that even a young forest restoration may accelerate seed rain of woody seedlings.

In general, the density of regenerated seedlings from the seed bank (24.3 seedlings/ $\mathrm{m}^{2}$ in 20 months) was much higher than from the seed rain (14.9 seedlings $\left./ \mathrm{m}^{2}\right)$, but this result was highly influenced by herbaceous species, which were more than four times denser than woody species (32.2 and 7.0 seedlings $/ \mathrm{m}^{2}$, respectively). When only woody species were considered, the density (seed rain with 11.2 seedlings $/ \mathrm{m}^{2}$, seed bank with 16.8 seedlings $/ \mathrm{m}^{2}$ ) was low when compared to the seed rain and seed bank of woody seedlings of other tropical forest studies: seed rain from 619 to 810 seeds/ $\mathrm{m}^{2} /$ year (Barbosa \& Pizo 2006, Marques \& Oliveira 2008) and seed bank from 48 to 389 seeds $/ \mathrm{m}^{2}$ (Grombone-Guaratini \& Rodrigues 2002, Baider et al. 2001). These results are probably due the differences in the seed survey methods. Here we evaluated emerged seedlings in situ in contrast to other studies where only seeds were assessed. This suggests that mortality is high in seeds from seed rain or seed banks. In fact, seedling emergence in tropical rainforests may be only a small fraction $(<3 \%)$ of the total seed density (Marques \& Oliveira 2008) and the interpretation of seed rain and seed bank surveys should consider this effect.

The distribution of recruited plant density from the seed bank and seed rain depended on the site for both herbaceous and woody species. Herbaceous species decreased in density and species richness (seed rain and seed bank) from the abandoned pasture to the old-growth forest. It is possible that the shaded habitat in the restored and old-growth forests prevents seedling emergence of these herbaceous and shade intolerant species. Despite the marginal contribution of these species to the total diversity and biomass of the tropical forest, herbaceous species play an important role in the first phases of 
pasture succession (Aide et al.1995, Saulei \& Swaine 1988, Dupuy \& Chazdon 1998, Wijdeven \& Kuzze 2000, Luzuriaga et al. 2005). On the other hand, woody species density and species richness were particularly expressive in the young restored forest (seed bank and seed rain). It was particularly important species such as Euterpe edulis (an endegered and rare species) and Cytharexylum myrianthum (an animal dispersed species). It is possible that the grass-dominated abandoned pasture prevented the regeneration of woody species because of numerous barriers to establishment and growth. These include seed and seedling predation and root competition with old pasture vegetation (Nepstad et al. 1991).

The seed bank was more important to improve seedling density and species richness in almost all situations but not in the old-growth forest (woody and herbaceous species). Recruitment from transient or persistent soil seed banks has long been considered an important pathway for regeneration of tropical pioneer species (Hall \& Swaine 1980, Lawton $\&$ Putz 1988). The low solar radiation present in the old-growth forest may possibly prevent seed bank recruitment. Also, studies of tropical soil seed banks have shown that they are often dominated by light-demanding species that have the potential for long term viability in the soil (Uhl \& Clark 1983, Hopkins \& Graham 1983), but these species germinate only when a gap is created. On the other hand, seed rain was particularly important in the old-growth forest. It is possible that this is due the abundance of dispersal agents, which inhabit the forest (all species were zoochorous). Also it has been well documented that seed rain is fundamental to primary forest species regeneration (Uhl et al. 1981, Whitmore 1983, Vasquez-Yanes \& Orozco-Segovia 1984, Young et al. 1987, AlvarezBuylla \& Garcia-Barrios 1991, Ribbens et al. 1994, Webb \& Peart 1999). The young restored forest provided beneficial conditions for regeneration from seed rain. Additionally, in the young restored forest, the seed rain treatments showed a higher percentage of woody species than the seed bank. In this case, the presence of small planted trees (3-4m high) could have influenced the recruitment of these woody species as they act as perching sites for birds that disperse these forest immigrant seeds through fecal voiding (Guevara et al. 1986, Holl 1998). Also, the shaded habitat below the crowns possibly restrained the regrowth of Brachiaria, thereby facilitating the recruitment of woody species. Woody seed input from off-site is crucial because other establishment mechanisms are potentially reduced or eliminated by years of grazing (Holl 1999).

In conclusion, although the regeneration of mainly woody species was low in all sites, it appears that the introduction of new woody species in the abandoned pastures (young restored forest) accelerated the regeneration of woody species. These results point to the importance of planted native forests for recovering the biodiversity of the degraded Atlantic Rain Forest.

\section{ACKNOWLEDGMENTS}

Many thanks to the Sociedade de Pesquisa em Vida Selvagem e Educação Ambiental (SPVS) for permitting us to work in the Rio Cachoeira Reserve and to the staff for their assistance. To Dominic Standing for revising the English version and for suggestions on the manuscript. To Ricardo M. Britez and Larissa Mellinger for their suggestions on the first version of the manuscript. To the Brazilian Research Council (CNPq) and the German Research Council (BMBF) for their support of the work in the Solobioma Project (690148/011). To Andre X. Lima, Victor Zwiener and Fernanda G. Cardoso for their assistance in the field. F.H.M. Leitão thanks CNPq for the fellowship. M.C.M. Marques thanks the grants from Brazilian Education Council (CAPES, Post-doc grant) and Brazilian Research Council (CNPq, Productivity grant). E. Ceccon thanks the PAPIIT- UNAM (IN118306) grant for financial support. 


\section{RESUMEN}

La introducción de plántulas en pastizales abandonados es una técnica común de restauración de los bosques en los trópicos, debido a que incrementa el reclutamiento de plántulas y acelera la sucesión. En este estudio se evaluó el papel de un bosque restaurado joven (un año) en el reclutamiento de plántulas a través de dos fuentes (lluvia y banco de semillas) en la región del Bosque Atlántico en el sur de Brasil. Se comparó un pastizal abandonado, un bosque restaurado joven y un bosque secundario maduro en cuanto al reclutamiento de plántulas de diferentes fuentes, mediante el monitoreo permanente de 40 parcelas $(0.5 \mathrm{mx} 0.5 \mathrm{~m})$ durante 20 meses. En las tres áreas estudiadas se reclutaron 392 plántulas de 53 especies, principalmente herbáceas $(85 \%)$, pioneras $(88 \%)$, zoocoras $(51 \%)$ y de semilla pequeña $(60 \%)$. El reclutamiento de plántulas en el banco de semillas (densidad y riqueza de especies) fue el más alto y dominado por especies herbáceas en el pasto abandonado y en el bosque restaurado joven, el reclutamiento de especies leñosas por la lluvia de semillas fue más pronunciado en los bosques secundarios maduros. Cuando se compara con el pastizal abandonado, el bosque restaurado joven presentó una mayor riqueza de plántulas de especies leñosas reclutadas, tanto del banco (el doble) como de la lluvia de semillas (tres veces más); la densidad de plántulas en el bosque restaurado joven fue más alta que en los pastizales abandonados (cuatro veces en el banco y diez veces en la lluvia de semillas). Nuestros resultados muestran que las áreas restauradas aún jóvenes pueden aumentar el reclutamiento de especies leñosas y deben considerarse como un paso importante para la restauración de pastizales.

Palabras clave: lluvia de semillas, banco de semillas, restauración, reclutamiento, bosques tropicales

\section{REFERENCES}

Aide, T.M., J.K. Zimmerman, L. Herrera, M. Rosario \& M. Serrano. 1995. Forest recovery in abandoned tropical pastures in Puerto Rico. Forest Ecol. Manag. 77: 77-86.

Aide, T.M., J.K. Zimmerman, J.B. Pascarella, L. Rivera \& H. Marcano-Vega. 2000. Forest regeneration in a chronosequence of tropical abandoned pastures: implications for restoration ecology. Restor. Ecol. 8: $328-338$.

Allsopp, N. \& W.D. Stock. 1995. Relationships between seed reserves, seedling growth and mycorrhizal responses in 14 related shrubs (Rosidae) from a lownutrient environment. Funct. Ecol. 9: 248-254.

Alvarez-Buylla, E.R. \& R. Garcia-Barrios. 1991. Seed and forest dynamics: a theoretical framework and an example from the neotropics. Am. Nat. 137: 133154.

Baider, C., M. Tabarelli \& W. Mantovani. 2001. The soil seed bank during Atlantic forest regeneration in Southeast Brazil. Rev. Bras. Biol. 61: 35-44.

Barbosa, K.C. \& M.A. Pizo. 2006. Seed rain and seed limitation in a planted gallery forest in Brazil. Restor. Ecol. 14: 504-515.

Bazzaz, F.A. \& S.T.A. Pickett. 1980. Physiological ecology of tropical succession: a comparative review. Annu. Rev. Ecol. Syst. 11: 287-310.

Bazzaz, F.A. \& D.D. Ackerly. 1992. Reproductive allocation and reproductive effort in plants, p. 1-26 In M. Fenner (ed.). Seeds: the ecology of regeneration in plant communities. CAB International, Oxon, England.

Benítez-Malvido, J., M. Martínez-Ramos \& E. Ceccon. 2001. Seed rain vs. seed bank, and the effect of vegetation cover on the recruitment of tree seedlings in tropical successional vegetation. In J. Cramer \& S. Lied (eds.). Life forms and Dynamics in Tropical forests. "Dissertationes Botanicae" series 346: 185-203. Gebrueder Borntraeger Berlin, Stuttgart.

Brokaw, N. 1982. The definition of treefall gap and its effect on measures of forest dynamics. Biotropica 14: $158-60$

Carrière, S.M., M. André, P. Letourmy, I. Olivier \& D. McKey. 2002. Seed rain beneath remnant trees in a slash-and-burn agricultural system in Southern Cameroon. J. Trop. Ecol. 18: 353-374.

Capobianco, J.P.R. 2001. Dossiê Mata Atlântica. RMA, ISA, SNE. Brasilia, Brazil.

Ceccon, E., P. Huante \& J. Campo. 2003. Effects of nitrogen and phosphorus fertilization on the survival and recruitment of seedlings of dominant tree species in two abandoned tropical dry forests in Yucatán, Mexico. For. Ecol. Manag. 182: 387-402.

Ceccon, E., S. Sanchéz \& J. Campo 2004. Tree seedling dynamics in two abandoned tropical dry forests of differing successional status in Yucatán, Mexico: a field experiment with $\mathrm{N}$ and $\mathrm{P}$ fertilization. Plant Ecol. 170: 12-26.

DeWalt, S.J., J.S. Denslow \& I. Kalan. 2004. Naturalenemy release facilitates habitat expansion of the invasive tropical shrub Clidemia hirta. Ecology 85: 471-483. 
Dupuy, J.M. \& R.L. Chazdon. 1998. Long- term effects of forest regrowth and selective logging on the seed bank of tropical forests in NE Costa Rica. Biotropica 30: 223-237.

Ellison A.M., J. Sloan, B.A. Denslow, D.B. Loiselle \& D.M. Brenes. 1993. Seed and Seedling Ecology of Neotropical Melastomataceae. Ecology 74: 17331749 .

Erskine, P.D., J.A. Parrotta \& D. Lamb. 2005. Restoration of degraded tropical forest landscapes. Science 310 : $1628-1632$

Fearnside, P.M. 1993. Deforestation in Brazilian Amazonia: The effect of population and land tenure. Ambio 22: $537-545$

Ferretti, A.R. \& R.M. Britez. 2006. Ecological restoration, carbon sequestration and biodiversity conservation: The experience of the Society for Wildlife Research and environmental education (SPVS) in the Atlantic Rain Forest of Southern Brazil. J. Nat. Cons. 14: 249-259.

Florentine, S.K. \& M.E. Westbrooke. 2004a. Restoration on abandoned tropical pasturelands - do we know enough? J. Nat. Cons. 12: 85-94.

Florentine, S.K. \& M.E. Westbrooke. 2004b. Evaluation of alternative approaches to rainforest restoration on abandoned pastures in tropical North Queensland. Land Degrad. Dev. 15: 1-13.

Grime, J.P., G. Masong, A.V. Curtis, J. Rodmax, S.R. Band, A.G. Mowforthm, M. Neal \& S. Shaw. 1981. A comparative study of germination characteristics in a local flora. J. Ecol. 69: 1017-1059.

Grombone-Guaratini, M.T. \& R.R. Rodrigues. 2002. Seed bank and seed rain in a seasonal semi-deciduous forest in South Eastern Brazil. J. Trop. Ecol. 18: 759-774.

Guariguata-Urbano, M.R., R. Rheingans \& F. Montagnini 1995. Early woody invasion under tree plantations in Costa Rica: implications for forest restoration. Rest. Ecol. 3: 252-260.

Guariguata, M.R. \& R. Ostertag. 2001. Neotropical secondary succession: changes in structural and functional characteristics. For. Ecol. Manag. 148: 185-206.

Guevara, S., S.E. Purata \& E. Van der Maarel. 1986. The role of remnant forest trees in tropical secondary succession. Plant Ecol. 66: 77-84.

Hall, J.B. \& M.D. Swaine. 1980. Seed stocks in Ghanaian forest soils. Biotropica 12: 256-263.
Harper, J.L. 1977. Population biology of plants. Academic, London, England.

Harper, J.L., P.H. Lovell \& K.G. Moore. 1970. The shapes and sizes of seeds. Ann. Rev. Ecol. Syst. 1: 327-351.

Holl, K.D. 1998. Do bird perching structures elevate seed rain and seedling establishment in abandoned tropical pasture? Rest. Ecol. 6: 253-261.

Holl, K.D. 1999. Factors limiting tropical rain forest regeneration in abandoned pasture: seed rain, seed germination, microclimate, and soil. Biotropica 31 : 229-242.

Hooper, E., P. Legendre \& R. Condit. 2005. Barriers to forest regeneration of deforested and abandoned land in Panama. J. Appl. Ecol. 42: 1165-1174.

Hopkins, M.S. \& A.W. Graham. 1983. Tree species composition of soil seed banks beneath lowland tropical rain forests in North Queensland, Australia. Biotropica 15: $90-99$.

Lamb, D., P.D. Erskine \& J. Parrotta. 2005. Restoration of degraded tropical forest landscapes. Science 310 : $1628-1632$

Lawton, R.O. \& F.E. Putz. 1988. Natural disturbance and gap-phase regeneration in a wind-exposed tropical cloud forest. Ecology 69: 764-777.

Lieberman, D. \& M. Lieberman. 1987. Forest tree growth and dynamics at La Selva, Costa Rica (1969-1982). J. Trop. Ecol. 33: 347-358.

Luzuriaga, A.L., A. Escudero, J.M. Olano \& J. Loidi. 2005 Regenerative role of seed banks following an intensive soil disturbance. Acta Oecol. 27: 57-66.

Mabberley, D.J. 1992. Tropical Rain Forest Ecology. Blackie, Glasgow, England.

Marques, M.C.M. \& P.E.A.M. Oliveira. 2008. Seasonal rhythms of seed rain and seedling emergence in two tropical rain forests in Southern Brazil. Plant Biol. 10: 596-603.

Metcalfe, D.J. \& I.M. Turner. 1998. Soil seed bank from lowland rain forest in Singapore: canopy-gap and litter-gap demanders. J. Trop. Ecol. 14: 103-108.

Miller, P.M. \& J.B. Kauffman. 1998. Seedling and sprout response to slash-and-burn agriculture in a tropical deciduous forest. Biotropica 30: 538-546.

Molofsky, J. \& C. Augspurger. 1992. The effect of leaf litter on early seedling establishment in a tropical forest. Ecology 73: 68-77. 
Morellato, L.P.C. \& C.F.B. Haddad. 2000. Introduction: The Brazilian Atlantic Forest. Biotropica 32: 786792 .

Müller-Dombois, D. \& H. Ellenberg. 1974. Aims and methods of vegetation ecology. Jon Wiley, New York, U.S.A.

Myers, N., C.G. Mittermeier, R.A. Mittermeier, G.A.B. Fonseca \& J. Kent. 2000. Biodiversity hotspots for conservation priorities. Nature 403: 853-858.

Nepstad, D.C., C. Uhl \& E.A.S. Serrao. 1991. Recuperation of a degraded Amazonian landscape: Forest recovery and agricultural restoration. Ambio 20: 248-255.

Pakeman, R.J. \& J.L. Small. 2005. The role of the seed bank, seed rain and the timing of disturbance in gap regeneration. J. Veg. Sci. 16: 121-130.

Pijl, L. van der. 1972. Principles of dispersal in higher plants. Springer, Berlin, Germany.

Rasiah, V., S.K. Florentine, B.L. Williams \& M.E. Westbrooke. 2004. Soil properties dynamics under abandoned pasture in deforested tropical rainforest in Australia. Geoderma 120: 35-45.

Ribbens, E., J.A. Silander \& S.W. Pacala. 1994. Seedling recruitment in forests: calibrating models to predict patterns of tree seedling dispersion. Ecology 75: 1794-1806.

Roderjan, C.V. \& Y. Kuniyoshi. 1988. Macrozoneamento florístico da Área de Proteção Ambiental - APA Guaraqueçaba. FUPEF - Série Técnica 15: 1-53.

Ruiz-Jaen, M.C. \& T.M. Aide. 2005. Restoration success: how is it being measured? Rest. Ecol. 13: 569-577.

Sarmiento, L., L.D. Llambí, A. Escalona \& N. Marquez. 2003. Vegetation patterns, regeneration rates and divergence in an old-field succession of the high tropical Andes. Plant Ecol. 166: 63-74.

Saulei, S.M. \& M.D. Swaine. 1988. Rain Forest seed dynamics during succession at Godol, Papua New Guinea. J. Ecol. 76: 1133-1152.

Scarano, F.R. 2002. Structure, function and floristic relationships of plant communities in stressful habitats marginal to Brazilian Atlantic Forest. Ann. Bot. 90: 517-524.

Schupp, E.W., T. Milleron \& S.E. Russo. 2002. Dissemination limitation and the origin and maintenance of species- rich tropical forests, p. 19-33. In D.J. Levey, W.R. Silva \& M. Galetti (eds.). Seed dispersal and frugivory: Ecology, evolution, and conservation. $\mathrm{CAB}$ International, Oxon, England.

Shono, K., E.A. Cadaweng \& P.B. Durst. 2007. Application of assisted natural regeneration to restore degraded tropical forestlands. Rest. Ecol. 15: 620-626.

Simões, C.G. \& M.C.M. Marques. 2007. The role of sprouts in the restoration of Atlantic Rain Forest in southern Brazil. Rest. Ecol. 15: 53-59.

Swaine, M.D., D. Lieberman \& F.E. Putz. 1987. The dynamics of tree populations in tropical forest: a review. J. Trop. Ecol. 3: 359-366.

Swaine, M.D. \& T.C. Whitmore. 1988. On the definition of ecological species groups in tropical rain forests. Vegetatio 75: 81-86.

Uhl, C., K. Clark, H. Clark \& P. Murphy. 1981. Early plant succession after cutting and burning upper Rio Negro region of Amazon Basin. J. Ecol. 69: 631-49.

Uhl, C. \& K. Clark. 1983. Seed ecology on selected Amazon basin succesional species. Bot. Gaz. 144: 419-423.

Van der Wall, S. 1994. Removal of wind dispersed pine seeds by ground-foraging vertebrates. Oikos 69: 125-132.

Vázquez-Yanez, C. 1974. Studies germination of seeds of Ochroma lagopus Swarts. Turrialba 24: 176-179.

Vázquez-Yanes, C. \& A. Orozco-Segovia. 1984. Ecophysiology of seed germination in the tropical humid forest of the world: a review, p. 37-50. In E. Medina, H.A. Mooney \& C. Vázquez-Yanes (eds.). Physiological ecology of plants of the wet tropics. Junk, The Hague, The Netherlands.

Veloso, H.P., L. Rangel Filho \& J.L. Lima. 1991. Classificação da vegetação brasileira adaptada a um sistema universal. IBGE. Departamento de Recursos Naturais e Estudos Ambientais do Rio de Janeiro. Rio de Janeiro, Brasil.

Vieira, L.M. \& A. Scariot. 2006. Principles of natural regeneration of tropical dry forests for restoration. Rest. Ecol. 14: 11-20.

Webb, C.O. \& D.R. Peart. 1999. Seedling density dependence promotes coexistence of Bornean rain forest trees. Ecology 80: 2006-2017. 
Whitmore, T.C. 1983. Secondary succession from seed in tropical rain forests. For. Abst. 44: 767-779.

Wijdeven, S.M.J. \& M.E. Kuzze. 2000. Seed availability as a limiting factor in forest recovery processes in Costa Rica. Rest. Ecol. 8: 414-424.

Yarranton, G.A. \& R.G. Morrison. 1974. Spatial dynamics f a primary succession: nucleation. J. Ecol. 62: 417-428.
Young, K.R., J.J. Ewel \& B.J. Brown. 1987. Seed dynamics during forest succession in Costa Rica. Vegetatio 71: 157-173.

Zar, J.H. 1999. Bioestatistical analysis. Prentice Hall, New Jersey, USA.

Zimmerman, J.K., J.B. Pascarella \& T.M. Aide. 2000. Barriers to forest regeneration in an abandoned pasture in Puerto Rico. Rest. Ecol. 8: 350-360. 